\title{
Early phenomenology in Poland (1895-1945): origins, development, and breakdown
}

\author{
Witold Płotka ${ }^{1}$
}

Published online: 9 March 2017

(C) The Author(s) 2017. This article is published with open access at Springerlink.com

\begin{abstract}
This article presents the development of the phenomenological movement in Poland in the period 1895-1945. It focuses on the early reactions to phenomenology and the later consolidation of the group of phenomenologists in Lvov. The article also explores the context of Polish phenomenology, its main figures, and their texts. The author suggests that early phenomenology in Poland was a pluralistic discipline that developed in polemical discussions, including discussions with members of the Lvov-Warsaw school. Finally, the article summarizes the major contributions of phenomenologists to philosophy, psychology, and aesthetics in Poland.
\end{abstract}

Keywords Phenomenological movement · Descriptive psychology · Lvov-Warsaw school · Twardowski $\cdot$ Ingarden $\cdot$ Blaustein

\section{Introduction}

Phenomenology in Poland has a long tradition. This fact has been highlighted by the recent publication of two important books, namely, a bibliography of Polish works related to Husserl (Bęben and Ples-Bęben 2013a) and a collection of selected articles connected to or using phenomenology and published in the pre-war period (Bęben and Ples-Bęben 2013b). Following Głombik (1999a, 2005, 2011), both books show that the very first Polish thinker who refered to Husserl was Władysław Heinrich (1869-1957), who published his review of Husserl's Philosophie der Arithmetik in German as early as 1895. In turn, the first text on Husserl in Polish was published in 1904 by Jan Łukasiewicz (1878-1956), a prominent member of the

Witold Płotka

witoldplotka@gmail.com

1 Institute of Philosophy, Sociology and Journalism, University of Gdańsk, Jana Bażyńskiego 4, 80-309 Gdańsk, Poland 
Lvov-Warsaw school. These basic facts are, however, not very well known. Even more, the contributions of early Polish phenomenology to, and its influence on, contemporary philosophy have remained rather unexplored, and they are usually reduced to Roman Ingarden's (1893-1970) philosophy. ${ }^{1}$

In this article I aim to provide an introduction to the context, main figures, and texts of the phenomenological movement in Poland in the period 1895-1945. In addition, I seek to present the main trends of early Polish phenomenology in order, on this basis, to formulate a diagnosis of the pre-war phenomenological movement in Poland. A further aim is to show that phenomenology in Poland has been a pluralistic movement that has known centers, e.g., figures such as Ingarden, but also peripheries, in this way deepening our understanding of what phenomenology was and can be. Phenomenology in Poland has been indeed a rich and complex movement. It was shaped in and through a lively dialog, and this included a critical confrontation with the Lvov-Warsaw school. At the same time, the scope of phenomenology in Poland is irreducible to academic philosophy or to the single discipline of philosophy. To the contrary, phenomenology has also been present, even prominent, in artistic, psychological, and sociological circles. Even more, due to historical circumstances, phenomenology was engaged in political contexts. Investigating this latter aspect, Gubser (2014) claims that phenomenology determined a part of the theoretical basis for Solidarity and resistance to the communist regime in Poland in the 1970s and 1980s. Thus research into phenomenology in Poland is a question of different areas of interests, periods, topics, and focuses. Indeed, Bęben (2012) defines five stages in the development of the phenomenological movement in Poland: (1) first reactions (1895-1918), (2) the Lvov Circle (1919-1945), (3) the Cracow and Lublin Circles (1946-1970), (4) the period from Ingarden's death to the fall of communism (1971-1989), and (5) contemporary phenomenology (1990-present). This periodization is a useful tool for understanding Polish phenomenology because it combines historical and systematic aspects of the phenomenon. In the following account, I will focus on the first and second stages to which I give the name "early phenomenology."

\section{First reactions: 1895-1918}

Although Husserl's early work Philosophie der Arithmetik (1891) is usually regarded as a pre-phenomenological work that develops an account of the concept of number based mainly and mostly on descriptive psychology, it does contain some ideas that came to be included in the foundation of mature phenomenology. Reacting constructively to criticism, Husserl soon resolved to overcome the psychologism afflicting his early work. In this connection, his Logische Untersuchungen (1900/1901) was a breakthrough work, because here Husserl formulated the main arguments against psychologism in logic and laid a methodological basis for phenomenology. This widely discussed work brought fame to its author, and it

\footnotetext{
${ }^{1}$ Cf. Spiegelberg (1999), Górniak-Kocikowska (1997). For critique see Woleński (1999).
} 
opened for him the path to a professorial position at the University of Göttingen (1901). In Poland, both works of Husserl raised serious academic interest.

Heinrich published his critical and polemical review of Husserl's Philosophie der Arithmetik in Vierteljahrsschrift für wissenschaftliche Philosophie in 1895. Earlier he had studied in Zurich and Munich where he wrote his dissertation under Richard Avenarius (1843-1896). After his return to Poland, he worked at the Jagiellonian University in Cracow. In the review, written in Vienna, Heinrich focused on methodological issues. In his view, one can investigate concepts in a twofold manner, namely either by bringing their different layers of development to clear insight (klare Einsicht) into their value and scope, or by describing their present stage of development (Heinrich 1895, 436-437). As Heinrich claims, Husserl employs the latter method, although it is inadequate because it describes only the "What" (Was) of arithmetical concepts. On the other hand, a more important question concerns the "How" (Wie) of mathematical concepts. After all, following Heinrich, concepts are in a state of permanent change and development. By describing merely the static structure of the concept of number, Husserl in his Philosophie der Arithmetik was not able to express the complex and dynamic construction of counting. In a word, Heinrich $(1895,438)$ recommends a genetic investigation rather than a static description. He appreciates, of course, Husserl's differentiation between a number symbol and a number concept. He emphasizes, however, that Husserl's analysis of counting is limited only to some parts of arithmetic, but cannot be applied to mathematics in general. Głombik (1999a, 150) notes that there is no evidence that Husserl ever took notice of Heinrich's review. Indeed, the secondary literature pays much more attention to Husserl's reaction to the famous review of Gottlob Frege (1848-1925). ${ }^{2}$

Although it seems that Heinrich did not influence him, it may not be an exaggeration to say that Husserl's early thought was shaped by another PoleKazimierz Twardowski (1866-1938). ${ }^{3}$ It is well known that Twardowski's influence on Polish philosophy is pervasive. He is commonly regarded as the founder of the Lvov-Warsaw school of logic (Woleński 1985, 1989). Like Husserl, Twardowski studied philosophy in Vienna under Franz Brentano (1838-1917). Unlike Husserl, however, he completed his dissertation under Robert von Zimmermann (1824-1898). ${ }^{4}$ Twardowski influenced Husserl in regard to the theory of acts, and, as a result, in regard to the critique of psychologism. In his early work Zur Lehre vom Inhalt und Gegenstand der Vorstellungen (1894), Twardowski argues

\footnotetext{
${ }^{2}$ Cf. Frege (1894), Mohanty (1982), Drummond (1985), McIntyre (1987), Hill and Rosado Haddock (2000).

3 On Husserl's interpretation of Twardowski, see Woleński (1997), 15-24. Cavallin claims that “[a]ctually, Twardowski's work might even be described as having a 'triggering' effect, both for the development of Husserl's first version of phenomenology, centered around the criticism of psychologism in philosophy, and for the second stage of Husserl's phenomenology, that is 'pure' or 'transcendental' phenomenology" (Cavallin 1997, 29).

${ }^{4}$ Husserl studied in Vienna from 1884 to 1886, and Twardowski from 1885 to 1889. Rollinger, who has investigated the relation between both philosophers, notes that "[d]uring the year 1885, when Husserl and Twardowski were both studying under Brentano, they must have had some contact with each other. But the complete lack of information about any such contact suggests that the relation need not have been a close one" (Rollinger 1999, 139).
} 
that an "immanent phenomenon" such as a mental act must be regarded as involving three elements: content, object, and presentation (Twardowski 1894, 3). The object is irreducible to the act, but the act refers to its object by virtue of its content. Husserl discussed this theory while working on the theory of intentional objects and his critique of psychologism, and moreover, he reviewed Twardowski's Zur Lehre vom Inhalt und Gegenstand der Vorstellungen. ${ }^{5}$ Twardowski had also a strong influence on phenomenology in Poland. For example, he encouraged his Lvov students, including Ingarden, Bronisław Bandrowski (1879-1914), ${ }^{6}$ Stefan Błachowski (1889-1962), ${ }^{7}$ and Kazimierz Ajdukiewicz (1890-1963) ${ }^{8}$ to study philosophy in Göttingen. Another student of his, Stanisław Leśniewski (1886-1939), who is known for the construction of three nested formal systems, regarded Husserl's philosophy as one of the sources of his own view of philosophy. ${ }^{9}$ Yet it was Łukasiewicz, a student of Twardowski, a logician, and an interpreter of Aristotle's syllogistic, who published the first work on Husserl in Polish. In a short note, he summarized Husserl's arguments against psychologism, pointing out that psychological laws are only probable, whereas logical laws are reliable (Łukasiewicz 1904, 476). ${ }^{10}$ He formulated two arguments to show that psychological laws are probable: (1) they involve real objects, and thus they are based on an inductive, i.e., probable, manner of inference; and (2) reliable laws are laws in the case of which negation entails contradiction, but the negation of psychological laws cannot be contradicted, so that they are only probable (Łukasiewicz 1904, 477). Łukasiewicz clearly declared that he adopted Husserl's arguments against psychologism from his Logische Untersuchungen. Later he enhanced the arguments by proposing that: (1) psychologism involves content different from that of logic

\footnotetext{
5 Husserl (1979), 303-356. Cf. Schuhmann (1993), Cavallin (1997), Rollinger (1999) and Miśkiewicz (2009).

${ }^{6}$ Bardrowski studied for two semesters in Göttingen in 1905/1906. He used phenomenology mainly in psychology, and, although he accepted Husserl's anti-psychologism, he was mainly interested in the theory of imaginary consciousness. He claimed that each mental state is intentional, i.e., it is directed towards its object due to meaning mediation. Bandrowski used phenomenology in his analysis of the phenomenon of thinking. Cf. Bandrowski (1907), Głombik (1999a).

7 Błachowski was a psychologist who was connected mainly with the university in Poznań, though he cooperated with Twardowski. He studied in Göttingen from 1909 to 1913 under Georg E. Müller (1850-1934). He also studied with Husserl. Phenomenological psychology was based for him on introspection enabling investigation of the psyche itself, regardless of personal feelings or physiological processes. Cf. Błachowski (1912), Głombik (1999a, 2011), Bęben and Ples-Bęben (2013b, 61-63).

8 Ajdukiewicz studied for two semesters in Göttingen in 1913/1914. During this period, he cooperated with Adolf Reinach (1883-1917). Ajdukiewicz was interested more in Reinach's theory (he prepared for Reinach a study entitled Ein Beitrag zur Analyse des Bewegungsbegriffes) than in Husserl's phenomenology. Nonetheless, one can note Husserl's influences on Ajdukiewicz's semantics, especially in regard to meanings as the essences of meaning-intending acts. Cf. Olech (1995), Głombik (1999a, 2005, 2011).

9 Leśniewski refers to Husserl several times in his dissertation on existential judgments. He also refers to Husserl's interpretation of John Stuart Mill's (1806-1873) logic, and discusses Husserl's thesis that one name can refer to many objects only because of its equivocation. Cf. Woleński (1985, 80, 140), Leśniewski (1911, 1927, 169).

10 Woleński (2010, 464), who calls this short text of Łukasiewicz "a classical text in Polish philosophy," states that Łukasiewicz's main task in his text is to coordinate Husserl's arguments against psychologism with mathematical logic.
} 
(psychological vs. logical content); (2) from the fact that logical operations are instantiated by psychic actions it does not follow that logic is bound to the human psyche; and, lastly, (3) psychologism confuses judgment in the sense of a psychic act with judgment in the sense of a logical proposition (Łukasiewicz 1907, 489-490).

It is worth noting that the first Polish student of Husserl in Göttingen was Aleksander Rozenblum-Augustowski (1883-1950), who began his studies (under Heinrich) at the Jagiellonian University in Cracow in 1902. In 1905, he moved to Göttingen, where he studied for ten semesters. Rozenblum was a co-founder of the Göttinger Philosophische Gesellschaft in 1907 (Schuhmann 1977, 103). He participated in Husserl's seminars, but also in Reinach's classes. Rozenblum was interested mainly in the question of the phenomenological method. Later he cooperated with the Munich Circle. ${ }^{11}$ In 1908, he presented in Reinach's seminar a talk on Łukasiewicz: Analysis and Constitution of the Concept (Schuhmann and Smith 1987, 14). In his correspondence, Husserl mentions Rozenblum a few times. ${ }^{12}$ Rozenblum was a very active member of the Göttingen and Munich Circles, though he did not publish any text. In 1924, a short note was published that reported Rozenblum's talk on Husserl's theory of knowledge at the meeting of the Warsaw Philosophical Institute. In this talk, Rozenblum (1924) argued that for Husserl every theory apprehended as a system of deductively connected propositions is dogmatic, because it is founded on a petitio principii. This also holds for the theory of knowledge. For this reason, the theory of knowledge should involve the idea of knowledge understood as the fulfillment of an empty intention (Rozenblum 1924, 267).

Władysław Tatarkiewicz (1886-1980), a student of the Marburg neo-Kantians and a member of the Lvov-Warsaw school, published the first comprehensive study of phenomenology. His article "Szkoła fenomenologów" ("The school of phenomenologists") (1913) presented phenomenology both as the phenomenological movement initiated by Husserl and as a specific philosophical method. He understands intuition, as opposed to deduction and induction, as the basis of phenomenological analysis. According to Tatarkiewicz (1913, 259-260), phenomenology seeks to disclose universal essences that are irreducible to general concepts. Rather, essences are involved both in general concepts and in individual beings. A further aim of phenomenology is the description of relations between essences. Tatarkiewicz appended to his article a list of works of phenomenologists, including books by Husserl, Reinach, and Pfänder. Tatarkiewicz's article was important for the reception of phenomenology in Poland because it did not relate merely to Husserl's philosophy in particular, but rather was an attempt to present phenomenology as a distinct discipline.

\footnotetext{
11 Alexander Pfänder (1870-1941), one of the leaders of the Munich Circle, emphasized that he corresponded with Rozenblum. Pfänder also emphasized that Rozenblum (together with Ingarden) was involved in the project of translating his Logik (1921) and Einführung in die Psychologie (1904). Cf. Pfänder's letters to Husserl from January 17, 1920, and from May 2, 1921. Cf. Husserl (1994b, 160, 167).

12 Cf. Husserl's letter to Winthrop Pickard Bell (1884-1965) from August 11, 1920, and letters to Ingarden from July 18 and December 30, 1920, June 20 and August 6, 1921. Cf. Husserl (1994c, 16, 204, 208, 211-213).
} 
Though the period 1895-1918 was the beginning of the phenomenological movement in general, phenomenology resonated throughout Polish academic life in many respects. Ingarden reviewed the second edition (from 1913) of Husserl's Logische Untersuchungen. ${ }^{13}$ Rozenblum attempted to translate the work, but he eventually abandoned the project. $^{14}$ In addition, Konstanty Michalski ${ }^{15}$ (1879-1947) and Joachim Metallman ${ }^{16}$ (1889-1942) referred to some elements Husserl's theory of knowledge. During this period, Polish thinkers tried not only to define the basic concepts and methods of phenomenology, or to engage in initial polemics, but also, and first of all, they tried to use phenomenology as a methodological tool. At this point, phenomenology encountered its first criticisms in Poland: (1) it was accused of using difficult, technical vocabulary, and, as a result, of being a vague philosophy; (2) its critique of the sciences was regarded as misguided because sciences simply are successful; and (3) its arguments were judged inconclusive and lacking in impact on psychology. ${ }^{17}$ Thus the first reactions to phenomenology in Poland encompass not only commentaries on many aspects of phenomenological philosophy but also constructive criticism of it.

\section{The Lvov circle: 1919-1945}

The second phase of the development of phenomenology in Poland had a central figure, namely Ingarden, and it is closely connected to his teaching activities at Lvov University. Weqgrzecki $(2001,17)$ calls this period the "Lvov period," and claims that during this time phenomenology had only local influence, and was generally unknown in Warsaw, Cracow, or in Vilnius. Ingarden earned his doctorate with a dissertation on Bergson under Husserl at the University of Freiburg in 1918. After world war I, he returned to Poland, and already in 1919 he published an

\footnotetext{
13 In his review, Ingarden focuses on changes that Husserl introduced to the first edition of his work (1900/1901). According to Ingarden, Husserl changed his understanding of phenomenology, because, whereas in the first edition phenomenology was regarded as descriptive psychology, in the second edition it was rather transcendental philosophy, which focused on pure consciousness and the essences of pure experiences as such. One can notice this change, according to Ingarden, with respect to Husserl's discussion with Locke and Hume. Cf. Ingarden (1915).

14 Rozenblum suspended his plan to translate Husserl because he was informed that Leśniewski was already undertaking a similar initiative. Cf. Głombik (1999a, 56-62, 1999b).

15 Michalski was a philosopher and historian of philosophy. He completed his dissertation at the Higher Institute of Philosophy in Leuven in 1911. He focused on Husserl's reaction to psychologism. Later, between 1931 and 1932, he was elected Rector of the Jagiellonian University in Cracow. Cf. Michalski (1911).

16 Metallman was a student of Heinrich at the Jagiellonian University. His work was on the principle of economics as defined by Avenarius and Ernst Mach (1838-1916). The principle claims that the process of thinking is teleological, and that it strives to achieve its aim by exerting minimal efforts. According to Metallman, Husserl's idea of the symbolization of thought corresponds to an understanding of logic as an instantiation of thought economics. Cf. Metallman (1914).

17 The arguments were formulated by Bronisław Biegeleisen (1881-1963), a philosopher and psychologist who worked at the Lvov Technical University. He engaged with Husserl's idea of philosophy as a rigorous science. Husserl published his essay Philosophie als strenge Wissenschaft in 1911. Cf. Biegeleisen (1913).
} 
important two-part study entitled "Dạżenia fenomenologów" ["The aims of phenomenologists"] which popularized phenomenology in Poland as a distinct philosophical current (Tatarkiewicz 1971, 131). This pair of articles (Ingarden 1919a, b) represents a comprehensive historical and systematic study of the main topics of phenomenology, including (1) Husserl's early psychologism in his Philosophie der Arithmetik, (2) the critique of psychologism in logic, (3) the phenomenological requirement to limit analysis to direct experience, (4) the descriptive manner of investigation, (5) the a priori basis of the analysis of essences, and (6) a transcendental reformulation of phenomenology by the method of reduction that avoids the petitio principii problem. For Ingarden, the aims of the phenomenologists ultimately involve systematic and rigorous descriptions of the different domains of objects, and, as a result, the formulation of a formal and material ontology. Though the two articles did not raise the realism-idealism controversy directly, they indicated several pivotal issues that later defined Ingarden's critique of Husserl, for example, the question of the ontological neutrality of the reduction (Ingarden 1919b, 348-349). As is well known, Ingarden charged transcendental phenomenology with being a philosophy that leads towards metaphysical idealism. ${ }^{18}$ In any case, Ingarden emerged as a key figure of this period, both as a proponent and as a critic of phenomenology.

After his return from Germany, Ingarden worked as a teacher in a secondary school in Torun and later (from 1925 on) as a docent at Lvov University. Although Husserl interceded on his behalf to help him obtain a full position in Lvov at that time, ${ }^{19}$ it was only in 1933 that Ingarden was given a chair. In the 1920s, Ingarden attempted to translate Husserl's Logische Untersuchungen into Polish, but the project did not meet with a favorable response from publishers. ${ }^{20}$ In the 1930 s, Ingarden was already an internationally recognized scholar on the basis of his book Das literarische Kunstwerk (1931). In Lvov, by contrast, he felt himself a solitary phenomenological researcher, because logic was still the dominant discipline of philosophy (Krońska 1972, 62). In spite of this circumstance, he eventually established a group of talented scholars and researchers who though not necessarily his direct students developed phenomenology in new directions. As a result, the Lvov Circle of phenomenologists included psychologists, philosophers, and aestheticians, for example Salomon Igel (1889-1942), ${ }^{21}$ Walter Auerbach

\footnotetext{
18 The controversy defined the later reception of phenomenology in Poland in general. Cf. Ingarden's letter to Husserl (1994c, 183-200) from 1918. Cf. also Ingarden (1929a), Krzemicka (1939), Tischner (1972), Galarowicz (1982a, b), Wallner (1987), Bostar (1994) and Bielawka (2011).

19 Cf. Husserl's letter to Twardowski from July 13, 1928. Husserl (1994a, 181).

20 Ingarden tried to publish the translation in Lvov and in Warsaw. In this connection, he corresponded with Twardowski and Rozenblum. The publishers claimed that the vocabulary Husserl used in his book was too difficult, and, in addition, they wanted to support original contributions rather than mere translations. Cf. Głombik (1999a, 62-64, 1999b).

21 Igel was a student of Twardowski. He focused on the problem of feelings and referenced theories of Brentano and Husserl. He claimed that feelings are based on representations but that some of them have propositional character. Feelings, as Igel stated, are objective acts, i.e., they are object-directed. In this connection, he engaged not only with Brentano and Husserl (with his Logische Untersuchungen), but also with Twardowski, Pfänder, Theodor Lipps (1851-1914), Alexius Meinong (1853-1920), Paul Natorp (1854-1924), and Moritz Geiger (1888-1937). It is worth noting that Igel derived phenomenology from
} 
$(1900-1942),{ }^{22}$ Tadeusz Witwicki (1902-1970), ${ }^{23}$ Zofia Lissa $(1908-1980),{ }^{24}$ and Leopold Blaustein (1905-1942). ${ }^{25}$ It is worth noting that Blaustein is the author of the first monograph in Polish on Husserl's phenomenology: Husserlowska nauka o akcie, treści i przedmiocie przedstawienia (Blaustein 1928) [Husserl's Theory of the Act, Content, and the Object of the Presentation]. The book is a critical elaboration of Husserl's theory of act consciousness. Blaustein accepts Husserl's method of eidetic description, but he rejects the requirement that phenomenology has to suspend reference to the history of philosophy. Although he is critical of Husserl's method, he describes consciousness in terms of an intentional act that, following Husserl and Twardowski, contains both a presentational content and the object of a presentation. According to Blaustein (1928), Husserl did not differentiate consistently between experience and experiencing, and for this reason he cannot distinguish an experienced sensation from the act of sensation. As a result, experienced data are reduced to immanent experiences, and thus the object is reduced to an immanent object of consciousness itself. In Ingarden's (1929b, 316) view, Blaustein is not clear enough on this, because Husserl did indeed differentiate between experienced data and aspects (Abschattungen) of objects. If that is the case, then Husserl also distinguished consistently between the objective and the subjective aspects of experience.

The publication of Ingarden's Das literarische Kunstwerk (1931) was the beginning of the reception of phenomenology in aesthetics (e.g., Chwistek 1932; Kroński 1933; Blaustein 1935) as well as in artistic circles. In this connection, Blaustein (1930b, 1933, 1935b/1936) presented original but polemical studies on imaginative representations in art and on the cinema. In addition, the Polish avantgarde painter, writer, and philosopher Stanisław Ignacy Witkiewicz (a.k.a. Witkacy) (1885-1939) criticized Husserl's philosophy for being an abstract and static theory of consciousness. In his view, Husserl's major error was the reduction of the lived body. The transcendental ego, he argued (Witkiewicz and Ingarden 2002, 32-33), is an ephemeral ghost. Briefly, phenomenology leads towards metaphysical idealism that cannot describe the real world in terms of a bodily experience. For similar reasons, Witkacy criticized neo-positivism, and as a result he formulated a quasiLeibnizian monadology that comprehends the lived body as a substance and a monad (cf. Witkiewicz 2002a, b).

\section{Footnote 21 continued}

the philosophy of Carl Stumpf (1848-1936), a psychologist, a member of the Munich Circle, and the thinker to whom Husserl's Logische Untersuchungen were dedicated. Cf. Igel $(1919,1922)$.

22 Auerbach was a student of Twardowski, Ingarden, and Tadeusz Kotarbiński (1886-1981). He presented an interesting analysis of doubting by arguing that Husserl's reduction of doubting to questioning is unjustified. He understood phenomenology mainly as descriptive psychology, but his project was interdisciplinary and analytical. Cf. Auerbach (1931).

${ }^{23}$ Witwicki was a philosopher, psychologist, and teacher. In his writings, he discussed the phenomenological aspects of representation and investigated the character of act contents and its relation to the object. Cf. Witwicki (1931).

24 Lissa adapted Ingarden's theory of literary artwork to musicology and film studies. Cf. Lissa (1937), Helman (1975).

25 Blaustein was a student of Twardowski, Ajdukiewicz, and Ingarden. He also studied in Freiburg under Husserl in 1925. Cf. Blaustein (1930a), Rosińska (2005), Miskiewicz (2009). 
Phenomenology in Poland during the period 1919-1945 can be regarded as a consolidated philosophical movement that was developed by means of a series of polemics, studies, and discussions. ${ }^{26}$ The main area of research focused on the mental act in relation to its content and object. Yet phenomenology was also developed in new directions. For example, Czesław Znamierowski (1888-1967) developed Reinach's theory of social acts (Znamierowski 1921) and Eugeniusz Bautro (1891-1961) analyzed the reception of Husserl's theory in the philosophy of law (Bautro 1926). At the same time, phenomenology in Poland was open to international cooperation. For example, Tadeusz Kroński (1907-1958) held a fellowship in Prague in 1937/1938, where he worked together with Jan Patočka (1907-1977). Kroński (1939) published a critical review of Patočka's Přirozenysvět jako filisofický problem (1936) [The Natural World as a Philosophical Problem], in which he claimed that in fact Patočka's theory represents a version of idealism because he emphasized time over the real existence of the world. This period ends with world war II, which occasioned a dramatic breakdown of the phenomenological movement in Poland. Auerbach, Blaustein, Metallman, and Witkiewicz, for instance, died or were killed during the war. In addition, Ingarden could no longer teach at the university, though he worked on his magnum opus, published after the war, Spór o istnienie świata, vol. I (Ingarden 1947) [Controversy over the Existence of the World]. Post-war Poland, however, was a completely different state, a communist country in which phenomenology was relentlessly criticized by MarxistLeninist thinkers for its allegedly idealist and bourgeois character. ${ }^{27}$

\section{Conclusion}

Early phenomenology in Poland was developed as a reaction to the first phenomenological works published in Germany. The reception of Husserl's philosophy began in 1895 (Heinrich), but the Munich Circle was also a popular point of reference (Rozenblum, Tatarkiewicz, Igel). Of course, the reception was not passive but critical (Biegeleisen, Chwistek, Witkiewicz), and in turn it influenced Husserl (Twardowski, Ingarden). Phenomenology in Poland flourished as a pluralistic field of research that encompassed many distinct but intertwined topics and disciplines. Polish phenomenologists discussed classical issues of phenomenology, such as the structure of the acts of consciousness, the possibilities of the method of reduction, and the question of psychologism (Heinrich, Bandrowski, Łukasiewicz, Michalski, Ingarden, Blaustein, Bautro). In this connection, one can identify multiple

\footnotetext{
${ }^{26}$ Leon Chwistek (1884-1944), who interacted with Ingarden, accused phenomenology of obscurity, of using a poetic vocabulary, and of confusing logic with semantics. Cf. Chwistek (1922).

27 Ingarden became a professor at the Jagiellonian University in Cracow in 1946, but between 1949 and 1957 he was banned from teaching because he was regarded as an "enemy of materialism." A good example of the shift in the understanding of phenomenology is found in Kroński's review of Ingarden's Controversy over the Existence of the World. Kroński (1952) argued, as he had earlier done against Patočka, that Ingarden's theory is so-called "objective idealism," but he formulated an additional political argument by claiming that Ingarden's work does not correspond to the proletariat's interests adequately, and, moreover, that it represents the "bankruptcy of bourgeois philosophy." On the Marxist critique of phenomenology, see Martel (1967) and Łoziński (1975).
} 
formulations of phenomenology as descriptive psychology (Twardowski, Bandrowski, Błachowski, Igel, Auerbach, Witwicki) or as transcendental philosophy (Ingarden, Witkiewicz, Blaustein). Phenomenology was used or discussed with regard to epistemology (Rozenblum, Metallman, Ingarden, Blaustein, Witkiewicz), ontology (Ingarden, Krzmicka (Korńska), Kroński, Witkiewicz), logic and semantics (Ajdukiewicz, Leśniewski, Łukasiewicz, Chwistek), aesthetics (Ingarden, Chwistek, Lissa, Blaustein, Kroński), and social philosophy (Znamierowski, Bautro).

In the end, however, early phenomenology in Poland seems to have been shaped by two leading thinkers, namely, Twardowski and Ingarden. Although he was not a phenomenologist at all, Twardowski inspired and defined Polish phenomenology as focused on the question of psychologism and that of the relationship between act, content, and object. Especially the problem of content, which was widely discussed by Polish philosophers, appears to have been a typical topic of early phenomenology in Poland. A direct but critical student of Husserl, ${ }^{28}$ Ingarden merged and melded basic phenomenological terminology and Polish philosophical vocabulary and determined the later reception of phenomenology in Poland as concentrated on the realism-idealism controversy. Briefly, Ingarden taught phenomenology how to speak Polish. Although early phenomenology in Poland had its typical topics and problems, it is probably inaccurate to claim that the early phenomenological movement in Poland had the recognizable character of a philosophical school. We can, of course, indicate the main figures of early phenomenology in Poland, for example, Rozenblum, Ingarden, and Blaustein; by claiming this, I want to emphasize that during the period 1895-1945 only Ingarden seems to be a phenomenologist tout court. In turn, Rozenblum and Blaustein were prominent members of the phenomenological movement, however, they used also other methods than the phenomenological one, e.g., descriptive psychology, and the analytic method. Furthermore, such philosophers as Ajdukiewicz, Leśniewski or Łukasiewicz were not phenomenologists, but logicians and members of the LvovWarsaw school; nonetheless, they referred to some phenomenological ideas. Lastly, then, during the early period there was no Polish school of phenomenologists parallel to, for instance, the Lvov-Warsaw school. ${ }^{29}$ Yet, as this article shows, the collective contributions of the early Polish phenomenologists constitute an excellent enhancement of the invaluable heritage of Polish philosophy.

Open Access This article is distributed under the terms of the Creative Commons Attribution 4.0 International License (http://creativecommons.org/licenses/by/4.0/), which permits unrestricted use, distribution, and reproduction in any medium, provided you give appropriate credit to the original author(s) and the source, provide a link to the Creative Commons license, and indicate if changes were made.

\footnotetext{
${ }^{28}$ Husserl (1994c, 253) called Ingarden "the dearest and most faithful of my older disciples".

29 Tischner $(1981,21)$ suggests that Ingarden's philosophy was not popular before 1939 because of the dominant position of the Lvov-Warsaw school. Węgrzecki (2001, 12-13) and Duchliński (2011, 371) repeat Tischner's opinion, and they both claim that world war II made it impossible to further develop phenomenological research in Poland.
} 


\section{References}

Auerbach, W. (1931). O wątpieniu. In: Ksiega pamiatkowa Polskiego Towarzystwa Filozoficznego we Lwowie. 12. II. 1904.-12. II. 1929. Lwów: Polskie Towarzystwo Filozoficzne, 78-97.

Bandrowski, B. (1907). Psychologiczna analiza zjawiska myślenia. Przeglad Filozoficzny, 10(4), $518-531$.

Bautro, E. (1926). Husserlizm w teorji prawa. Czasopismo Prawnicze i Ekonomiczne, 24(1-12), $250-256$.

Bęben, D. (2012). Recepcja fenomenologii Edmunda Husserla w Polsce. Próba periodyzacji. Fenomenologia, 10, 107-123.

Bęben, D., \& Ples-Bęben, M. (2013a). Husserl w Polsce. Bibliografia 1895-2010. Katowice: Wydawnictwo Uniwersytetu Śląskiego.

Bęben, D., \& Ples-Bęben, M. (Eds.). (2013b). Polska fenomenologia przedwojenna. Antologia tekstów. Katowice: Wydawnictwo Uniwersytetu Śląskiego.

Biegeleisen, B. (1913). Uśmiechy Sfinksa. Z zagadnień współczesnej filozofji. Sfinks, 6(22), 161-187.

Bielawka, M. (2011). Spór z Ingardenowskim sporem o istnienie świata. In A. Węgrzecki (Ed.), W kregu myśli Romana Ingardena: praca zbiorowa (pp. 77-89). Wydawnictwo WAM: Kraków.

Błachowski, S. (1912). Czem jest i czem będzie psychologia?. Filareta, 2(9), 263-268.

Blaustein, L. (1928). Husserlowska nauka o akcie, treści i przedmiocie przedstawienia. Lwów: Nakładem Towarzystwa Naukowego z Zasiłkiem Ministerstwa Wyznań Religijnych i Oświecenia Publicznego.

Blaustein, L. (1930a). Edmund Husserl i jego fenomenologia. Przeglad Humanistyczny, 5(2), $233-242$.

Blaustein, L. (1930b). Przedstawienia imaginatywne. Studyum z pogranicza psychologii i estetyki. Lwów: Polskie Towarzystwo Filozoficzne.

Blaustein, L. (1933). Przyczynki do psychologii widza kinowego. Kwartalnik Psychologiczny, 4(1-4), 192-236.

Blaustein, L. (1935). Roman Ingarden. Das literarische Kunstwerk. Eine Untersuchung aus dem Grenzgebiet der Ontologie, Logik, und Literaturwissenschaft, Halle, Max Niemayer, 1931. Ruch Filozoficzny, 13 (5-10), 98-102.

Blaustein, L. (1935/36). O imaginatywnym świecie sztuki. Miesięcznik Literatury i Sztuki, 2(8-9), 243-249.

Bostar, L. (1994). Reading Ingarden read Husserl: Metaphysics, ontology, and phenomenological method. Husserl Studies, 10, 211-236.

Cavallin, J. (1997). Content and object Husserl, Twardowski and psychologism. Dordrecht: Kluwer.

Chwistek, L. (1922). Krótka rozprawa z panem Romanem Ingardenem, doktorem uniwersytetu fryburskiego. Przeglad Filozoficzny, 25(4), 541-544.

Chwistek, L. (1932). Tragedia werbalnej metafizyki. Kwartalnik Filozoficzny, 10(1), 46-76.

Drummond, J. J. (1985). Frege and Husserl. Another look at the issue of influence. Husserl Studies, 2, 245-265.

Duchliński, P. (2011). Fenomenologia polska. In A. Maryniarczyk et al. (Eds.), Encyklopedia filozofii polskiej (pp. 369-378). Polskie Towarzystwo Tomasza z Akwinu: Lublin.

Frege, G. (1894). Rezension von Dr. E. G. Husserl, Philosophie der Arithmetik. Zeitschrift für Philosophie und philosophische Kritik, 103, 313-332.

Galarowicz, J. (1982a). U podstaw sporu Ingardena z Husserlem. (I) Spór o metodę. Studia Filozoficzny, 186-187(3-4), 79-86.

Galarowicz, J. (1982b). U podstaw sporu Ingardena z Husserlem. (II) Spór o świadomość. Studia Filozoficzny, 188-189(5-6), 83-95.

Głombik, C. (1999a). Husserl i Polacy. Pierwsze spotkania, wczesne reakcje. Katowice: Wydawnictwo Gnome.

Głombik, C. (1999b). O niedoszłych polskich przekładach Logische Untersuchungen. In R. Wiśniewski \& W. Tyburski (Eds.), Polska filozofia analityczna. W kregu szkoły Lwowsko-Warszawskiej (pp. 89-106). Toruń: Wydawnictwo Uniwersytetu Toruńskiego.

Głombik, C. (2005). Die Polen und die Göttinger phänomenologische Bewegung. Husserl Studies, 21, $1-15$.

Głombik, C. (2011). Husserl und die Polen. Frühgeschichte einer Rezeption. Würzburg: Königshausen \& Neumann.

Górniak-Kocikowska, K. (1997). Poland. In L. Embree et al. (Eds.), Encyclopedia of phenomenology (pp. 537-543). Dordrecht: Kluwer. 
Gubser, M. (2014). The far reaches. Phenomenology, ethics, and social renewal in Central Europe. Stanford (CA): Stanford University Press.

Heinrich, W. (1895). Husserl, Dr. E. G., Philosophie der Arithmetik. Band 1. Halle a. S., Pfeffer (Stricker), 1891. Vierteljahrsschrift für wissenschaftliche Philosophie, 19(4), 436-439.

Helman, A. (1975). The influence of Ingarden's aesthetics on the theory of film. In P. Graff \& S. Krzemień-Ojak (Eds.), Roman Ingarden and contemporary polish aesthetics (pp. 97-108). Warsaw: Polish Scientific Publishers.

Hill, C. O., \& Rosado Haddock, G. E. (2000). Husserl or Frege? Meaning, objectivity, and mathematics. La Salle (IL): Open Court.

Husserl, E. (1979). Aufsätze und Rezensionen (1890-1910). The Hague: Nijhoff.

Husserl, E. (1994a). Briefwechsel. Band I. Die Brentanoschule (Vol. I). Dordrecht: Kluwer.

Husserl, E. (1994b). Briefwechsel. Band II. Die Münchener Phänomenologen (Vol. II). Dordrecht: Kluwer.

Husserl, E. (1994c). Briefwechsel. Band III. Die Göttinger Schule (Vol. III). Dordrecht: Kluwer.

Igel, S. (1919). Stosunek uczuć do przedstawień ze względu na klasyfikację faktów psychicznych. Przeglad Filozoficzny, 22(4), 352-418.

Igel, S. (1922). W sprawie nauki o zjawiskach zmysłowych uwag kilka. Przeglad Filozoficzny, 23, 110-126.

Ingarden, R. (1915). Logische Untersuchungen von Edmund Husserl, zwite, umgearbeitete Auflage; Halle a. d. S. Max Niemeyer 1913. Przeglad Filozoficzny, 18(3-4), 305-311.

Ingarden, R. (1919a). Dążenia fenomenologów. Przeglad Filozoficzny, 22(3), 118-156.

Ingarden, R. (1919b). Dążenia fenomenologów (Dokończenie). Przeglad Filozoficzny, 22(4), 315-351.

Ingarden, R. (1929a). Bemarkungen zum Problem "Idealismus-Realismus." Jahrbuch für Philosophie und phänomenologische Forschung, Ergänzungsband, 10, 159-190.

Ingarden, R. (1929b). Leopold Blaustein, Husserlowska nauka o akcie, treści i przedmiocie przedstawienia. Archiwum Towarzystwa Naukowego we Lwowie, Dział II. T. IV., Zesz. 3, Lwów 1928. Przeglad Filozoficzny, 32(4), 315-316.

Ingarden, R. (1931). Das literarische Kunstwerk. Eine Untersuchung aus dem Grenzgebiet der Ontologie. Logik und Literaturwissenschaft. Halle: Niemeyer.

Ingarden, R. (1947). Spór o istnienie świata. T. I. Kraków: Polska Akademia Umiejętności.

Krońska, I. (1972). Wspomnienie o profesorze Ingardenie w pierwszą rocznicę jego śmierci. In: Z. Augustynek et al. (Eds.), Fenomenologia Romana Ingardena. Wydanie specjalne, "Studiów Filozoficznych” (pp. 59-70). Warszawa: Instytut Filozofii i Socjologii Polskiej Akademii Nauk.

Kroński, T. J. (1933). Roman Ingarden: Das literarische Kunstwerk. Eine Untersuchung aus dem Grenzgebiet der Ontologie, Logik, und Literaturwissenschaft. Max Niemayer Verlag, Halle (Saale) 1931 X i 389 str. Przeglad Filozoficzny, 36(4), 387-391.

Kroński, T. (1939). Filozofia i świat naiwny. Ateneum. Czasopismo poświęcone sprawom kultury, 1(7), 126-131.

Kroński, T. (1952). Świat w klamrach ontologii. Myśl Filozoficzna, 1, 318-331.

Krzemicka, I. (1939). Filozofia Edmunda Husserla. Ateneum. Czasopismo poświecone sprawom kultury, 1(7), 117-125.

Leśniewski, S. (1911). Przyczynek do analizy zdań egzystencjalnych. Przeglad Filozoficzny, 14(3), 329-345.

Leśniewski, S. (1927). O podstawach matematyki. Przeglad Filozoficzny, 30(2-3), 164-206.

Lissa, Z. (1937). Muzyka i film. Studium z pogranicza ontologii, estetyki i psychologii muzyki filmowej. Lwów: Księgarnia Lwowska.

Łoziński, J. (1975). Uwagi o problemie stosunku marksizmu do fenomenologii: Rewolucja i PrawdaLenin i Husserl. Studia Filozoficzne, 10-11, 55-66.

Łukasiewicz, J. (1904). Z posiedzeń Polskiego Towarzystwa Filozoficznego. Przeglad Filozoficzny, 7(4), 476-477.

Łukasiewicz, J. (1907). Logika a psychologia. Przeglad Filozoficzny, 10(4), 489-492.

Martel, K. (1967). U podstaw fenomenologii Husserla. Warszawa: Wydawnictwo Książka i Wiedza.

McIntyre, R. (1987). Husserl and Frege. The Journal of Philosophy, 84(10), 528-535.

Metallman, J. (1914). Zasada ekonomii myślenia, jej historya i krytyka. Warszawa: Skład Główny w Księgarni E. Wende i S-ka.

Michalski, K. (1911). La réaction contre le psychologisme en Allemagne. Husserl, ses prédecésseurs et ses partisans. In: Michalski, K. (1999). Histoire de la Philosophie. Kraków: Wydawnictwo Instytut Teologiczny Księży Misjonarzy, 517-564. 
Miskiewicz, W. (2009). Leopold Blaustein's analytical phenomenology. In S. Lapointe et al. (Eds.), The golden age of Polish philosophy. Kazimierz Twardowski's philosophical legacy (pp. 181-188). Dordrecht: Springer.

Miśkiewicz, W. (2009). “...ganz spezielle philosophische Richtung...”. O recepcji fenomenologii Husserla w środowisku Twardowskiego. Przeglad Filozoficzny-Nowa Seria, 18(4), 181-191.

Mohanty, J. N. (1982). Frege and Husserl. Bloomington (IN): Indiana University Press.

Olech, A. (1995). Some remarks on Ajdukiewicz's and Husserl's approaches to meaning. Poznań Studies in the Philosophy of the Science and the Humanities, 40, 221-225.

Rollinger, R. D. (1999). Husserl's position in the school of Brentano. Dordrecht: Kluwer.

Rosińska, Z. (2005). Leopold Blaustein. Wybór pism estetycznych. Kraków: Universitas.

Rozenblum, A. (1924). O teorji poznania. Przeglad Filozoficzny, 27(3-4), 267-268.

Schuhmann, K. (1977). Husserl-Chronik. Denk- und Lebensweg Edmund Husserls. Den Haag: Nijhoff.

Schuhmann, K. (1993). Husserl and Twardowski. In F. Conglione et al. (Eds.), Polish scientific philosophy: The Lvov-Warsaw School (pp. 41-58). Amsterdam: Rodopi.

Schuhmann, K., \& Smith, B. (1987). Adolf Reinach. An intellectual biography. In K. Mulligan (Ed.), Speech and the Sachverhalt. Reinach and the foundations of realist phenomenology (pp. 1-27). Dordrecht: Nijhoff.

Spiegelberg, H. (1999). The phenomenological movement. A historical introduction (Third revisited and enlarged ed.). Dordrecht: Kluwer.

Tatarkiewicz, W. (1913). Szkoła fenomenologów. Ruch Filozoficzny, 3(10), 257-263.

Tatarkiewicz, W. (1971). Droga do filozofii i inne rozprawy filozoficzne. Tom I. Warszawa: Państwowe Wydawnictwo Naukowe.

Tischner, J. (1972). Ingarden-Husserl: spór o istnienie świata. In: Z. Augustynek et al. (Eds.), Fenomenologia Romana Ingardena. Wydanie specjalne „Studiów Filozoficznych” (pp. 127-143). Warszawa: Instytut Filozofii i Socjologii Polskiej Akademii Nauk.

Tischner, J. (1981). Polski ksztatt dialogu. Paris: Editions Spotkania.

Twardowski, K. (1894). Zur Lehre vom Inhalt und Gegenstand der Vorstellungen. Eine psychologische Untersuchung. Wien: Alfred Hölder.

Wallner, I. M. (1987). In defense of Husserl's transcendental idealism: Roman Ingarden's critique reexamined. Husserl Studies, 4, 3-43.

Węrzecki, A. (2001). Zarys recepcji fenomenologii w Polsce. In A. Strzałkowski (Ed.), Recepcja w Polsce nowych kierunków i teorii naukowych (pp. 9-20). Polska Akademia Umiejętności: Kraków.

Witkiewicz, S. I. (2002a). Pojecia i twierdzenia implikowane przez pojecie istnienia $i$ inne pisma filozoficzne (1902-1932). Warszawa: Państwowy Instytut Wydawniczy.

Witkiewicz, S. I. (2002b). Spór o monadyzm. Dwugłos polemiczny z Janem Leszczyńskim. Warszawa: Państwowy Instytut Wydawniczy.

Witkiewicz, S. I. \& Ingarden, R. (2002). Korespondencja filozoficzna. Warszawa: Wydawnictwo IFiS PAN, Collegium Civitas Press.

Witwicki, T. (1931). O stosunku treści do przedmiotu przedstawienia. In: Ksiega pamiatkowa Polskiego Towarzystwa Filozoficznego we Lwowie. 12. II. 1904.-12. II. 1929 (pp. 394-412). Lwów: Polskie Towarzystwo Filozoficzne.

Woleński, J. (1985). Filozoficzna szkoła lwowsko-warszawska. Warszawa: Państwowe Wydawnictwo Naukowe.

Woleński, J. (1989). Logic and philosophy in the Lvov-Warsaw School. Dordrecht: Kluwer.

Woleński, J. (1997). Szkoła lwowsko-warszawska w polemikach. Warszawa: Wydawnictwo Naukowe SCHOLAR.

Woleński, J. (1999). Summa Phenomenologiae. Kwartalnik Filozoficzny, 27(1), 182-185.

Woleński, J. (2010). Fenomenologia. In J. Skoczyński \& J. Woleński (Eds.), Historia filozofii polskiej (pp. 463-487). Wydawnictwo WAM: Kraków.

Znamierowski, Z. (1921). O przedmiocie i fakcie społecznym. Przeglad Filozoficzny, 24(1-2), 1-33. 